\title{
The effects of lactic acid bacteria-fermented soymilk extract on patients with colonic polyps: a randomized, double-blind, placebo-controlled pilot trial
}

Keita Odashiro *, Mitsuhiro Fukata *, Kazuyuki Saito **, Chikako Wakana **, Toru Maruyama ***, Yasuhiro Sasuga ****, Masaru Fukui ${ }^{* * * *}$, Takehiko Fujino **

大腸ポリープ患者に対する乳酸菌生成エキス（大豆乳酸菌発酵 抽出液）の効果：二重盲験比較試験によるパイロット試験

小田代敬太* · 深田光敬* · 斉藤和之** · 若菜智香子** .

丸山 徹 ${ }^{* * *}$. 貴家康尋 $* * *$ ・ 福井 勝 ${ }^{* * *}$ ・藤野武彦**

(*九州大学医学部第一内科, **BOOCS クリニック福岡, ***九州大学基幹研究院,

****株式会社ビーアンドエス・コーポレーション八王子研究所）

(平成25年11月 8 日受付, 平成26年 2 月 21 日受理)

* Department of Medicine and Biosystemic Science, Kyushu University Graduate School of Medical Sciences, 3-1-1, Maidashi, Higashi-ku, Fukuoka-shi, Fukuoka, 812-8582

**B BOOCS Clinic Fukuoka, 6-18-6F, Tenya-machi, Hakata-ku, Fukuoka-shi, Fukuoka, 812-0025

***Faculty of Arts and Science, Kyushu University, 6-1, Kasugakouen, Kasuga-shi, Fukuoka, 816-0811

**** Hachiouji Laboratory, B\&S Corporation Co., Ltd., 2-31-13, Akatsuki-cho, Hachiouji-shi, Tokyo, 192-0043

\footnotetext{
* $=812-8582$ 福岡県福岡市東区馬出 3-1-1

** $\bar{\top} 812-0025$ 福岡県福岡市博多区店屋町 6-18 $6 \mathrm{~F}$

***\%816-0811 福岡県春日市春日公園 6-1

****\%192-0043＼cjkstart東京都八王子市暁町 2-31-13
}

\begin{abstract}
大腸がんは世界的に発症例が増え，その予防と治療に多大な努力がなされている。 その予防対策として重視されているのが大腸ポリープ対策であり，次世代型の予防 対策として大腸ポリープの内視鏡による摘出から, 大腸ポリープを発症させない予防, あるいは外科的侵襲のないポリープ対策が期待される。その中で天然素材由来の成 分や食事は，がんの予防・リスク低減に向けて広く研究が進められている。これま でに，乳酸菌生成エキス（大豆乳酸菌発酵エキス，LDS）の経口摂取は，大腸がん 発生モデルマウスに扔いて, 初期大腸腺腫拧よび微小腺腫の発症率を著しく低下さ せることが明らかとなっている。本研究では，大腸ポリープ患者に対するLDS の経 口㠌取による治癒効果を二重盲験比較試験により検証した。その結果, 被験成分摂 取群（LDS $10 \mathrm{~mL} /$ 日摂取，6か月間）に打いて，ポリープの消失もしくは縮小が 8 症例中 5 症例で確認された。なお，被験成分を含まないプラセボ摂取群では，す心゙ ての症例に扔いて変化は認められなかった。これらの結果は, LDS の経口摄取は, 副作用なしに大腸ポリープの治癒あるいは予防に有効であることを示すものである。
\end{abstract}




\section{Introduction}

Colon cancer is the second to third most common type of cancer worldwide ${ }^{1)}$. In Japan, there have been changing trends in regional crude mortality rate, and the ratio of colon cancer has been increasing in contrast to gastric cancer over the last two decades. One effective countermeasure against colon cancer is resection of colonic polyps. With the progress of colonoscopy, now colonic polyps can be resected as well as diagnosed safely and easily. Although prevention of colon cancer has improved dramatically by polypectomy, it is expected that the future preventive measure will shift from resection to the inhibition of the onset of colonic polyps. Chemotherapy and radiotherapy have been applied as surgical therapies for colon cancer and polyps. However, these treatments may present some side effects. Recently, natural bioactive supplements and diet therapies have been widely investigated to reduce the risks of colon cancer and polyps ${ }^{2,3)}$.

The health benefits of lactic acid bacteria (LAB)-based products have been recognized in Japan and around the world. In fact, various types of LAB (as probiotics) and/ or LAB-fermented products have been developed and associated with several types of benefits in both human and animals including alleviation of lactose-intolerance symptoms, improvement of intestinal flora, modulation of specific/non-specific immune responses, reduction of serum cholesterol, prevention of pathogen infection, and reduction of colonic disease risks ${ }^{4-9)}$. Such health benefits have been observed not only in living micro-organisms but in killed micro-organisms, fermentation extracts, and secreted metabolites ${ }^{10-12}$. In the previous study, we demonstrated that the ingestion of lactic acid bacteria (LAB) dietary supplement (LDS) derived from extract of multi-strains LAB-fermented soymilk inhibited the early development of colon adenomas, and that inhibition of microadenomas resulted in the reduction of subsequent polyps and tumors in the tumor-inducing ICR male mice ${ }^{13)}$. These data suggest that LDS is useful in prevention and/or treatment of colonic polyps and colon cancer. To address this, we conducted a prospective, randomized, double-blind, placebocontrolled pilot clinical trial of LDS ingestion for 6 months in patients with colonic polyps to evaluate the effects of LDS on those polyps.

\section{Materials and Methods}

\section{(1) Study design and subjects}

A double-blind design was used. Subjects were randomly assigned into the article group (10 subjects), which was administered LDS, and the placebo group (10 sub- jects), which was administered the placebo drink. Each subject orally ingested $10 \mathrm{~mL}$ of LDS or placebo every morning and evening for 6 months. All subjects underwent colonoscopy and several clinical inspections before the initial administration and after 6 months. The subjects were also instructed to record supplement intake in a diary during the period.

This study was performed at BOOCS Clinic in Fukuoka city, Japan, from January 2011 to December 2011 in accordance with the Declaration of Helsinki. Twenty adult subjects, in whom colonic polyps were confirmed by colonoscopy, participated in this study. Exclusion criteria included any prior history of colitis, colon cancer, or any other malignancy; administration of antibiotics, corticosteroid and the symptoms of allergy to soy. This study was approved by the Clinic Ethics Committee, which required informed consents from all subjects before executing this study, in accordance with its ethical standards. This clinical trial is registered at UMIN Clinical Trials Registry as UMIN000008676.

\section{( 2 ) Test dietary supplement}

Test articles, the commercially available LDS (product name; CHITSU ${ }^{\mathrm{TM}}$ ) derived from extract of multi-strains LAB-fermented soymilk, and the placebo-control drink, were provided from B\&S Co., Ltd. (Tokyo, Japan). Sixteen-strains of LAB (as species Lb. acidphilus, Lb. brevis, Lb. casei, Lb. curvatus, Lb. fermentum, Lb. plantarum, $L b$. rhamnosus, Lb. salivarius) were used for soymilk fermentation, and the fermentation extract was used as a raw material for LDS with lactic acid and citric acid. For placebocontrol, the drink was prepared by using only lactic acid and citric acid so that it tasted similar to active LDS.

\section{( 3 ) Assessment}

All subjects were assessed with colonoscopic finding, physical characteristics [height, weight, body mass index (BMI), body fat percentage, waist circumference], blood pressure, blood biochemical values, and urine profile.

\section{(4) Statistical analysis}

The characteristics of subjects before and after ingestion of each dietary supplement were evaluated by using ttest for continuous variables, and $\chi^{2}$ test for categorical variables. Levels of significance were set at less than $5 \%$ for all statistical analyses.

\section{Results}

\section{(1) Disposition of subjects}

Four subjects (2 subjects in each group) conflicting 
Table 1 Characteristics of subjects participated in the study

\begin{tabular}{|c|c|c|c|c|}
\hline & \multicolumn{2}{|c|}{ Pre-ingestion } & \multicolumn{2}{|c|}{ Post-ingestion } \\
\hline & $\begin{array}{l}\text { Article group } \\
\quad(n=8)\end{array}$ & $\begin{array}{l}\text { Placebo group } \\
\quad(n=8)\end{array}$ & $\begin{array}{l}\text { Article group } \\
\quad(n=8)\end{array}$ & $\begin{array}{l}\text { Placebo group } \\
\quad(n=8)\end{array}$ \\
\hline Age & $63.1 \pm 15.6$ & $70.4 \pm 9.3$ & - & - \\
\hline Sex (male/female) & $5 / 3$ & $7 / 1$ & - & - \\
\hline Body mass index $\left(\mathrm{kg} / \mathrm{m}^{2}\right)$ & $23.3 \pm 2.4$ & $25.0 \pm 2.8$ & $22.9 \pm 2.0$ & $24.8 \pm 2.5$ \\
\hline Systolic blood pressure $(\mathrm{mmHg})$ & $127.5 \pm 11.4$ & $125.5 \pm 22.3$ & $128.6 \pm 13.9$ & $132.5 \pm 13.1$ \\
\hline Diastolic blood pressure $(\mathrm{mmHg})$ & $73.5 \pm 14.4$ & $72.4 \pm 10.7$ & $71.1 \pm 12.2$ & $76.6 \pm 8.2$ \\
\hline Number of polyps & $3.5 \pm 2.5$ & $2.0 \pm 0.9$ & $3.4 \pm 1.8$ & $2.1 \pm 1.1$ \\
\hline Size of polyps (mm) & $5.3 \pm 5.7$ & $4.9 \pm 4.6$ & $4.9 \pm 5.5$ & $4.9 \pm 4.5$ \\
\hline
\end{tabular}

Values show mean \pm standard error.

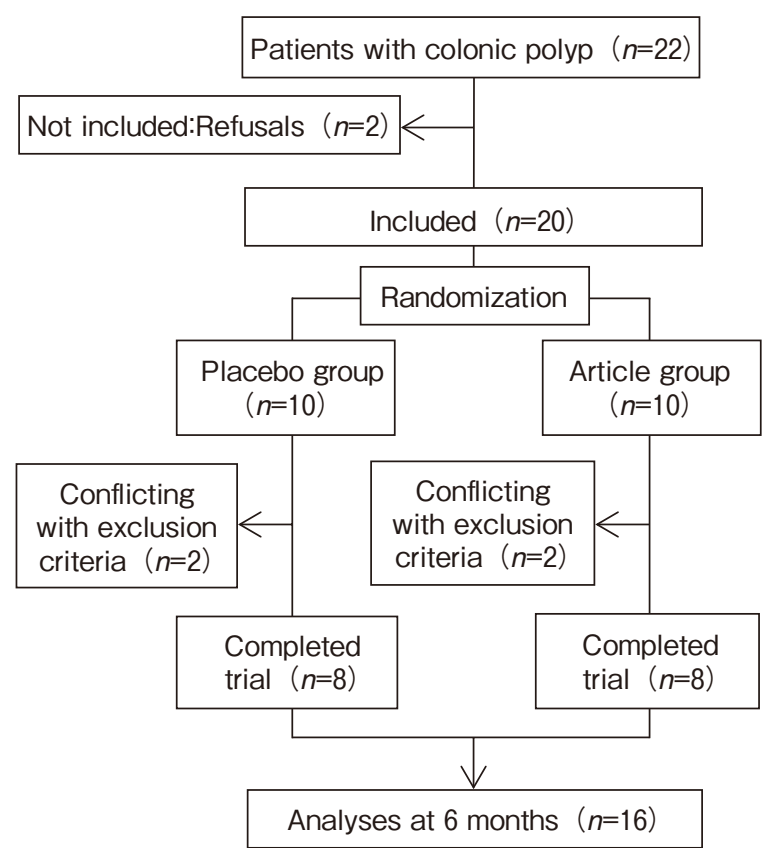

Fig. 1 Subjects flow through the study

with the exclusion criteria were excluded from the analysis and 16 subjects were evaluated (Fig. 1). At the initial screening, polyps were found in various regions of large intestines. Total $28(3.5 \pm 2.5 /$ patient $)$ and $16(2.0 \pm$ $0.9 /$ patient) polyps were observed in the article (A) group and the placebo $(\mathrm{P})$ group respectively. The size of the polyps was also varied and ranged from 2 to $30 \mathrm{~mm}$. There were no significant differences between $\mathrm{A}$ and $\mathrm{P}$ groups in the back ground data as shown in Table 1. It is noted that no significant differences were shown.

\section{( 2 ) Efficacy of LDS ingestion on polyp}

After 6 months, A group showed disappearance and reduction of polyps ( 4 in 3 cases and 2 in 2 cases respectively). In contrast, $P$ group revealed neither disappearance nor reduction of polyps (Table 2 ). This difference in the change of polyps between A and P groups was statistically significant under $\chi^{2}$ test $(p<0.01)$. Although total 28 polyps were observed in A group at pre-ingestion, 6 polyps
Table 2 Changes in the number of cases between pre- and post-ingestion

\begin{tabular}{lcc}
\hline \multicolumn{1}{c}{ Case } & $\begin{array}{c}\text { Article group } \\
(n=8)\end{array}$ & $\begin{array}{c}\text { Placebo group } \\
(n=8)\end{array}$ \\
\hline Disappearance & 3 & 0 \\
Reduction & 2 & 0 \\
Invariant & 3 & 7 \\
Deterioration & 0 & 0 \\
Appearance & 2 & 1 \\
\hline
\end{tabular}

Values show the number of cases.

disappeared or reduced their size after ingestion. On the other hand, improvement of polyps was not observed in $\mathrm{P}$ group (total 16 polyps were observed at pre-ingestion period) as shown in Table 3. As a result of $\chi^{2}$ test, disappearance and size reduction of polyps in A group were statistically significantly different $(p<0.05)$. In addition, the difference by the region of large intestines was not noticed in the number of polyps. New polyps appeared in 2 cases of $\mathrm{A}$ group and 1 case of $\mathrm{P}$ group. There were no significant differences between both groups in the number of new polyps.

\section{( 3 ) Body characteristics and blood chemistry}

There were no significant differences in body characteristics (Table 1) and blood biochemical values (Table 4) between pre- and post- ingestion in both $A$ and $P$ groups. LDL-cholesterol values were decreased significantly $(p<0.05)$ after the ingestion in both groups.

\section{(4) Safety}

Although six adverse events ( $\mathrm{P}$ group: 4 cases, A group: 2 cases) occurred during the test period, all of them were transient or incidental, and causal relationships with the article and placebo drink were denied. No other serious adverse event happened during this study, and safety of this treatment was confirmed. 
The effects of lactic acid bacteria-fermented soymilk extract on patients with colonic polyps: a randomized, double-blind, placebo-controlled pilot trial

Table 3 Changes in the number of polyps between pre- and post-ingestion

\begin{tabular}{|c|c|c|c|c|c|c|}
\hline \multirow{2}{*}{ Region } & \multicolumn{2}{|c|}{ Disappearance/Size reduction } & \multicolumn{2}{|c|}{ Invariant } & \multicolumn{2}{|c|}{ Apperance } \\
\hline & Article group & Placebo group & Article group & Placebo group & Article group & Placebo group \\
\hline Cecum & 0 & 0 & 2 & 2 & 0 & 0 \\
\hline Ascending colon & 2 & 0 & 3 & 1 & 2 & 1 \\
\hline Transverse colon & 1 & 0 & 3 & 6 & 1 & 0 \\
\hline Descending colon & 0 & 0 & 1 & 0 & 0 & 0 \\
\hline Sigmoid colon & 2 & 0 & 5 & 4 & 0 & 0 \\
\hline Rectum & 1 & 0 & 8 & 3 & 0 & 0 \\
\hline Total & 6 & 0 & 22 & 16 & 3 & 1 \\
\hline
\end{tabular}

Values show the number of polyps.

Table 4 Blood biochemical values of subjects participated in the study

\begin{tabular}{|c|c|c|c|c|}
\hline \multirow[b]{3}{*}{$\mathrm{HbAlc}(\%)$} & \multicolumn{2}{|c|}{ Pre-ingestion } & \multicolumn{2}{|c|}{ Post-ingestion } \\
\hline & $\begin{array}{l}\text { Article group } \\
\quad(n=8)\end{array}$ & $\begin{array}{l}\text { Placebo group } \\
\qquad(n=8)\end{array}$ & $\begin{array}{l}\text { Article group } \\
\quad(n=8)\end{array}$ & $\begin{array}{l}\text { Placebo group } \\
\quad(n=8)\end{array}$ \\
\hline & $5.33 \pm 0.90$ & $5.59 \pm 0.87$ & $5.11 \pm 0.75$ & $5.41 \pm 0.67$ \\
\hline Blood glucose (mg/dL) & $97.75 \pm 37.62$ & $113.25 \pm 39.42$ & $102.63 \pm 29.94$ & $105.13 \pm 26.62$ \\
\hline Total cholesterol $(\mathrm{mg} / \mathrm{dL})$ & $204.75 \pm 26.50$ & $226.38 \pm 28.51$ & $192.88 \pm 24.32$ & $209.00 \pm 17.09$ \\
\hline LDL-choresterol (mg/dL) & $126.63 \pm 20.65$ & $144.75 \pm 24.85$ & $112.13 \pm 14.88^{*}$ & $119.63 \pm 20.56^{*}$ \\
\hline HDL-choresterol (mg/dL) & $56.50 \pm 16.58$ & $53.25 \pm 12.04$ & $58.00 \pm 17.61$ & $57.75 \pm 12.35$ \\
\hline Triglyceride $(\mathrm{mg} / \mathrm{dL})$ & $116.00 \pm 84.66$ & $122.25 \pm 48.12$ & $117.50 \pm 98.90$ & $107.50 \pm 44.86$ \\
\hline $\operatorname{AST}(\mathrm{U} / \mathrm{L})$ & $26.00 \pm 16.15$ & $23.25 \pm 7.48$ & $24.50 \pm 10.17$ & $26.75 \pm 18.41$ \\
\hline $\operatorname{ALT}(\mathrm{U} / \mathrm{L})$ & $19.88 \pm 9.36$ & $23.38 \pm 13.90$ & $17.75 \pm 4.13$ & $27.00 \pm 29.87$ \\
\hline $\mathrm{LDH}(\mathrm{U} / \mathrm{L})$ & $209.50 \pm 37.26$ & $193.50 \pm 16.81$ & $210.13 \pm 49.17$ & $199.00 \pm 24.54$ \\
\hline Urea nitrogen $(\mathrm{mg} / \mathrm{dL})$ & $15.11 \pm 3.44$ & $18.60 \pm 10.50$ & $14.33 \pm 2.72$ & $16.29 \pm 4.84$ \\
\hline Creatinine $(\mathrm{mg} / \mathrm{dL})$ & $0.74 \pm 0.15$ & $0.92 \pm 0.43$ & $0.74 \pm 0.13$ & $0.87 \pm 0.35$ \\
\hline $\mathrm{CRP}(\mathrm{mg} / \mathrm{dL})$ & $0.23 \pm 0.42$ & $0.09 \pm 0.07$ & $0.08 \pm 0.04$ & $0.07 \pm 0.03$ \\
\hline NK activity E/T ratio $10: 1$ (\%) & $12.05 \pm 7.43$ & $14.15 \pm 5.07$ & $12.13 \pm 5.35$ & $12.80 \pm 9.05$ \\
\hline NK activity E/T ratio $20: 1$ (\%) & $21.00 \pm 12.82$ & $23.41 \pm 7.69$ & $19.76 \pm 8.66$ & $20.84 \pm 12.75$ \\
\hline
\end{tabular}

Values show mean \pm standard error. ${ }^{*}$ Significantly different between pre- and post-ingestion by t-test $(p<0.05)$.

\section{Discussion}

It is well known that diet and dietary supplements will be useful for the treatment of colonic polyps and/or colon cancer. For example, lactoferrin, iron binding glycoprotein discovered as a component of milk, could be a clinically beneficial assist to colonic polyp extraction ${ }^{3)}$. We also reported the remarkably preventive effects of LDS on colonic polyps of mice ${ }^{13)}$. To our knowledge, this study is the first clinical trial investigating the effect of LAB-fermented product on human colonic polyps. In the result, a 6-month ingestion of LDS induced elimination of existing polyps or significant reduction of polyp size in approximately $60 \%$ of the subjects without any side effects, whereas in the placebo group such improvements were not observed at all. These results confirm the therapeutic efficacy of LDS on human colonic polyps, although its effects on mice colonic polyps were already clarified by the previous study. The accurate mechanisms by which LDS affected on human colonic polyps were not directly investigated in this clinical trial. One possibility is that oral administration of LDS affects immune functions. In fact, it was demonstrated that the proportion and absolute number of CD1d-independent NK1. $1^{+} \mathrm{T}$ cells in the colon significantly increased after oral administration of LDS in mice. Also, interferon- $\gamma$ mRNA was prominently induced by LDS administration in NK1. $1^{+} \mathrm{T}$ cells in the colon ${ }^{14)}$. As well as our data, there are many reports for the immune modulation effect of LAB and LAB-related products $^{11,15-17)}$. In addition to this, some soluble secretion factors by LAB, cell wall components, such as peptidoglycan and lipoteichioc acid, and unmethylated CpG motifs DNA 
from LAB and other bacteria elicit proinflammatory immune responses ${ }^{18-21)}$. LDS also contains LAB secretion factors, cell wall components, and nucleic acid fraction as immunologic adjuvant. It seems that these multi components in LDS affect immune function interactively.

Several agents, including nonsteroidal antiinflammatory drugs, such as aspirin, aminosalicylates and cyclooxygenase-2 (COX-2) inhibitor, have been evaluated for their potential in chemoprevention of colon cancer $^{22,23)}$. These agents can prevent growth of polyps, reduce their size, or complete regression. However, they are associated with side effects so it is important to consider the risk-benefit ratio before recommending them for chemoprevention ${ }^{24)}$. Diet and dietary supplements are also important factors in colonic polyps and/or colon cancer. Natural bioactive supplements and diet therapies have very few side effects.

Researches on the health impacts of $L A B$ have been advanced significantly in recent years, and LAB and LABrelated products have been reported to have many beneficial effects on both human and animals, as one of natural bioactive supplements. Protective roles of LAB-related products on colon cancer have also been studied in many different ways ${ }^{2)}$. Our results indicate that ingestion of LDS is useful and safe for the treatment of colonic polyps through a randomized, double-blind, controlled clinical trial. However, there are two issues in this study as follows: (I) the small number of cases, (II) the shortness of the test period. To address these issues and to characterize the effects of LDS for prevention and treatment of colonic polyps, further studies are needed hereafter.

In conclusion, this randomized double-blind clinical trial of LDS ingestion in patients with colonic polyps has confirmed that a 6-months ingestion of $10 \mathrm{~mL}$ of LDS per day induced elimination of existing colonic polyps or significant reduction of polyp size in approximately $60 \%$ of the subjects, which is expected to have significant effects on colonic polyp regression without any side effects.

\section{Acknowledgments}

We thank Ms. Noriko Tokoro for her experimental coordination, and the members of BOOCS Clinic for their skillful assistance.

\section{References}

1) Ferlay J, Shin H-R, Bray F, Forman D, Mathers C, Parkin DM : Estimates of worldwide burden of cancer in 2008: GLOBOCAN 2008, Int J Cancer, 127, 2893-2917 (2010)

2 ) Liong M-T: Roles of probiotics and prebiotics in colon cancer prevention: postulated mechanisms and in-vivo evidence, Int J Mol Sci, 9, 854-863 (2008)

3 ) Kozu T, Iinuma G, Ohashi Y, Saito Y, Akasu T, Saito D,
Alexander DB, Ligo M, Kakizoe T, Tsuda H: Effect of orally administered bovine lactoferrin on the growth of adenomatous colorectal polyps in a randomized, placebo-controlled clinical trial, Cancer Prev Res, 2, 975-983 (2009)

4 ) Wollowski I, Rechekemmer G, Pool-Zobel BL: Protective role of probiotics and prebiotics in colon cancer, Am J Clin Nutr, 73 (suppl), 451S-455S (2001)

5 ) Yamano T, lino H, Takada M, Blum S, Rochat F, Fukushima Y: Improvement of the human intestinal flora by ingestion of the probiotic strain Lactobacillus johnsonii La 1 , Br J Nutr, 95, 303-312 (2006)

6) Parvez S, Malik KA, Ah Kang S, Kim H-Y: Probiotics and their fermented food products are beneficial for health, $J$ Apple Microbiol, 100, 1171-1185 (2006)

7 ) Damaskos D, Kolios G: Probiotics and prebiotics in inflammatory bowel disease: microflora 'on the scope', $\mathrm{Br} \mathrm{J} \mathrm{Clin}$ Pharmacol, 65, 453-467 (2008)

8 ) Lee DK, Jang S, Baek EH, Kim MJ, Lee KS, Shin HS, Chung MJ, Kim JE, Lee KO, Ha NJ: Lactic acid bacteria affect serum cholesterol levels, harmful fecal enzyme activity, and fecal water content, Lipids Health Dis, 8, 21 (2009)

9) Chenoll E, Casinos B, Bataller E, Astals P, Echevarría J, Iglesias JR, Balbarie P, Ramón D, Genovés S: Novel probiotic bifidobacterium bifidum CECT7366 strain active against the pathogenic bacterium Helicobacter pylori, Apple Environ Microbiol, 77, 1335-1343 (2011)

10) Ménard S, Candalh C, Bambou JC, Terpend K, CerfBensussan N, Hyman M : Lactic acid bacteria secrete metabolites retaining anti-inflammatory properties after intestinal transport, Gut, 53, 821-828 (2004)

11) Zeuthen LH, Christensen HR, Frøkiær H: Lactic acid bacteria inducing a weak interleukin-12 and tumor necrosis factor alpha response in human dendritic cells inhibit strongly stimulating lactic acid bacteria but act synergistically with gramnegative bacteria, Clin Vaccine Immunol, 13, 365-375 (2006)

12) Heuvelin E, Lebreton C, Grangette C, Pot B. CerfBensussan N, Heyman M: Mechanisms involved in alleviation of intestinal inflammation by Bifidobacteruim breve soluble factors, PLoS ONE, 4 , e5184 (2009)

13) Fukui M, Fujino T, Tsutsui K, Maruyama T, Yoshimura H, Shinohara T, Fukui M, Nada O: The tumor-preventing effect of a mixture of several lactic acid bacteria on 1,2-dimethylhydrazine-induced colon carcinogenesis in mice, Oncol Rep, 8 , 1073-1078 (2001)

14) Takahashi S, Kawamura T, Kanda Y, Taniguchi T, Nishizawa T, Iiai T, Hatakeyama K, Abo T: Activation of CD1d-independent NK1. $1^{+} \mathrm{T}$ cells in the large intestine by Lactobacilli, Immunol Lett, 102, 74-78 (2006)

15) Nagao F, Nakayama M, Muto T, Okumura K: Effects of fermented milk drink containing Lactobacillus casei strain Shirota on the immune system in healthy human subjects, Biocsi Biotechnol Biochem, 64, 2706-2708 (2000)

16) Galdeano CM, Perdigón G: The probiotic bacterium Lactobacillus case $i$ induces activation of the gut mucosal immune system through innate immunity, Clin Vaccine Immunol, 13, 219-226 (2006)

17) Foligne B, Zoumpopoulou G, Dewulf J, Younes AB, Chareyre F, Sirard J-C, Pot B, Grangette C: A key role of den- 
The effects of lactic acid bacteria-fermented soymilk extract on patients with colonic polyps: a randomized, double-blind, placebo-controlled pilot trial

dritic cells in probiotic functionality, PLoS ONE, 32, e313 (2007)

18) Peña J A., Versalovic J: Lactobacillus rhamnosus GG decreases TNF-a production in lipopolysaccharide-activated murine macrophages by a contact-independent mechanism, Cell Microbiol, 5, 277-285 (2003)

19) Matsuguchi T, Takagi A, Matsuzaki T, Nagaoka M, Ishikawa K, Yokokura T, Yoshikai Y: Lipoteichoic acids from Lactobacillus strains elicit strong tumor necrosis factor alpha-inducing activities in macrophages through toll-like receptor 2, Clin Diagn Lab Immunol, 10, 259-266 (2003)

20) Sparwasser T, Koch E S, Vabulas R M, Heeg K, Lipford G B, Ellwart J W, Wagne R H: Bacterial DNA and immunostimulatory $\mathrm{CpG}$ oligonucleotides trigger maturation and activation of murine dendritic cells, Eur J Immunol, 28, 2045-2054 (1998)

21) Iliev D I, Kitazawa H, Shimosato T, Katoh S, Morita H, He F, Hosoda M, Saito T: Strong immunostimulation in murine immune cells byLactobacillus rhamnosusGG DNA containing noveloligodeoxynucleotide pattern, Cell Microbiol, 7, 403-414 (2005)

22) Dubé C, Rostom A, Lewin G, Tsertsvadze A, Barrowman N, Code C, Sampson M, Moher D: The use of aspirin for primary prevention of colorectal cancer: a systematic review prepared for the U.S. preventive services task force, Ann Intern Med, 146, 365-375 (2007)

23) Rostom A, Dubé C, Lewin G, Tsertsvadze A, Barrowman N, Code C, Sampson M, Moher D: Nonsteroidal anti-inflammatory drugs and cyclooxygenase- 2 inhibitors for primary prevention of colorectal cancer: a systematic review prepared for the US preventive services task force, Ann Intern Med, 146, 376389 (2007)

24) Cooper K, Squires H, Carroll C, Papaioannou D, Booth A, Logan RF, Maguire C, Hind D, Tappenden P: Chemoprevention of colorectal cancer: systematic review and economic evaluation, Health Technol Assess, 14, 1-206 (2010) 